\title{
Journal of Educational Sciences
}

Journal homepage: https://jes.ejournal.unri.ac.id/index.php/IES

\section{Development of Learning Tools by Application of Problem Based Learning Models to Improve Mathematical Communication Capabilities of Sequence and Series Materials}

\author{
Nur Atika*, Yenita Roza, Atma Murni \\ Mathematics Education Studies Program, FKIP, Universitas Riau, Pekanbaru, 28293, Riau, Indonesia
}

\section{ARTICLE INFO}

\section{Article history:}

Received: 06 July 2019

Revised: 14 Oct 2019

Accepted: 05 Jan 2020

Published online: 24 Jan 2020

\section{Keywords:}

Learning Tools

PBL

Mathematical Communication Skills

Sequences

\begin{abstract}
A B S T R A C T
This research was motivated by the lack of learning tools that can improve students' Mathematical Communication Skills (KKM). Activities that can encourage students to improve KKM have not been designed by the teacher in the learning device properly. This study aims to produce learning tools by applying Problem Based Learning models to improve KKM. This development research used the ADDIE development model with the stages of Analysis, Design, Development, Implementation, and Evaluation. The results of Syllabus, RPP, LKPD and KKM validation results showed highly valid criteria with percentages of $91.67 \%, 91.30 \%, 89.09 \%$, and $87.15 \%$, respectively. Practicality results indicate a very practical criterion with the percentage of small group trials at $95.57 \%$, large group trials at $96.07 \%$, and teacher responses at $96.25 \%$. The effectiveness test results state that KKM of students who use learning tools with PBL models is better than KKM of students who use conventional learning.
\end{abstract}

\section{Introduction}

The paradigm shift in the administration of education requires a change from conventional teacher-centered learning processes to teacher-centered learning that makes the role of teachers more complex, because teacher demands are not just teaching and educating students but are also expected to be able to become facilitator so that the role of education becomes more meaningful. Puji et al. (2019) says that in education, the learning process is identified by the process of conveying information or communication. The 2013 curriculum implemented in schools requires teachers to prepare a design of learning activities that can encourage learners' activities in learning. Guswinda et al. (2019) said that the

\footnotetext{
${ }^{*}$ Corresponding author. Tel./Fax.: +628127551846

E-mail: atika_ibnuhajar@yahoo.co.id
} 
teacher acts as a facilitator and mediator to encourage students to carry out learning activities. Teachers must be creative in designing learning activities so that the learning process can be carried out and in accordance with those listed in Permendikbud Number 22 of 2016.

Learning tools are a form of preparation done by teachers before conducting the learning process (Daryanto et al. 2014). Sumarno et al. (2014) said that the learning tools are used as a teacher's guide in implementing the learning process in class so that the learning process can take place more directed towards the competencies to be achieved. Appropriate learning tools are a very important factor in preparing students to gain learning experiences. Sumarno et al. (2014) also said that the design and use of good learning tools is strongly suspected to be able to further improve student learning outcomes. The teacher can make the lesson plan as a guide in the implementation of learning in the classroom by utilizing LKPD to teach students.

Syllabus is a learning plan that is prepared systematically and contains interrelated components to meet the objectives of achieving Basic Competence (KD). Syllabus is used as a reference in developing lesson plans. RPP is a guide to learning activities carried out by teachers in learning. The characteristics of a good lesson plan according to Jumanta (2016) include the activities that can make the experience for students, learning steps arranged systematically, and in detail. LKPD is a learning device as a complement or supporting tool for teachers in implementing learning plans. Hanim et al. (2017) said that a good LKPD is one that can help and guide students in understanding the material and can increase the activities of students.

The learning tools used by the teacher have not been able to facilitate the KKM of students. The teacher has not developed learning devices independently according to the characteristics of students. Based on the results of interviews with five high school mathematics teachers, there is one teacher who develops learning tools independently. Other teachers tend to use devices from peers, download internet, previous devices and have their credentials adjusted, even buying CDs of learning tools at a low cost. Learning tools are only limited to administrative requirements provided by the teacher without regard to the objectives to be achieved. Some teachers have not been able to develop indicators of competency achievement using operational verbs that can measure KD achievement, have not been able to formulate learning objectives by paying attention to aspects of audience, behavior, conditions, and degrees, learning activities have not been arranged clearly and systematically based on learning models that make activities students are more active, and LKPD is not utilized in learning activities.

In learning at school, Rahman (in Yenita et al. 2017) states that mathematics is the most difficult subject for students compared to other subjects. The teacher needs to design learning that makes students not think that mathematics is difficult. However, learning done by teachers tends to be at the teacher center. Student participation in learning is still limited. The structure of the students' activities in the learning device has not been planned systematically, clearly, and does not 
involve the participation of the students so that the learning activities cannot yet facilitate the KKM of the students. Dedeh (2013) said that communication skills are higher order thinking skills that are important to be developed.

Wahid (2012) said that KKM is one of the heart in learning, so it is necessary to develop and develop mathematics learning activities. Student KKM in the field still looks very low. This can be seen from the results of the initial KKM test given to 30 students. The indicators used in measuring KKM in this study are: (1) the ability to express daily events in mathematical language or symbols; (2) the ability to use terms / notations / formulas and structures to present ideas; and (3) draw conclusions from the solutions provided.

From 30 students, there are 10 people who can determine things that are known and asked, 12 people who can use the terms / notations / formulas and structure correctly, and 10 people who are able to draw conclusions from the solutions provided. There are still many students who have not been able to state everyday events in language or mathematical symbols from the given elaboration questions. This shows that the learning activities designed by the teacher have not been able to facilitate the KKM of students.

Based on the problems that have been described above, activities that can improve the KKM of students need to be planned properly. Anik (2017) said the learning tools developed are said to be of quality if they meet three criteria, namely valid, practical, and effective. Learning activities in the learning device are expected to make active student activities in learning by applying the learning model. The learning model used must be able to create an active interaction between students and students as well as students with learning objects, so that students can independently find the concepts of the material being taught (Miftahul et al. 2019). Learning models that can make active student participation in learning one of them is the Problem Based Learning (PBL) model. Fatia (2013) said that in PBL students can work in groups and must identify what they know and what they don't know and must learn to solve problems. Learning activities in the PBL model will be more meaningful because students seek, find, and build their own knowledge so that the knowledge will be stored long in the memory of students (Titi et al. 2017). The purpose of this study is to develop learning tools by applying PBL learning models to improve KKM on valid, practical, and effective sequence and series material.

\section{Methodology}

The development model that had been used in this study was the ADDIE model. The ADDIE development model is an acronym for Analysis, Design, Development, Implementation, and Evaluation which is the stage of developing learning tools. Nancy et al. (2013) said that the ADDIE model is a model that can adapt very well in a variety of conditions. The level of flexibility of this model in answering problems is quite high, is effective to use, and provides a general and structured framework. The subjects of this study were students of class XI of SMAN 5 Pekanbaru. 
The first stage of the ADDIE model is the analysis phase. The analysis that had been carried out was a performance analysis and a needs analysis. Performance analysis was carried out to find out the difficulties encountered by the teacher in the learning process. Needs analysis was done to find out the problems faced by students in learning. The second stage was the design stage. At this stage, the collection of relevant references as material to design learning tools on sequences and series were carried out. The design of learning tools was adapted to the Basic and Secondary Education Process Standards and applies PBL models and scientific approaches.

The third stage was the development stage, which was the stage of producing or realizing syllabus, RPP, and LKPD designs that have been determined. Learning devices that have been produced are then validated by experts. The validation of the learning kit was carried out by two mathematics education lecturers and one mathematics teacher in grade XI of high school mathematics subject. The results of the validation conducted were then analyzed and revised according to the suggestions of the validator.

The fourth stage was the implementation phase or testing of learning tools. Learning devices that have been said to be valid were then tested. The trial was conducted on a small group of 12 people with heterogeneous abilities aimed at seeing the readability of LKPD and large groups of 35 people who aimed to determine the level of practicality of the learning tools that had been developed. Andri et al. (2019) said that the practicality of learning tools was obtained from field trials.

The fifth stage was the evaluation stage. The evaluation phase was carried out in two forms, namely formative and summative evaluation. Formative evaluations were carried out at the end of each face-to-face meeting and summative evaluations were carried out after the activity ends as a whole.

Analysis of the data in this study was the validation sheet analysis, response questionnaire analysis, and analysis of KKM test results. Validation sheet analysis was obtained by determining the average percentage of validation from the validator. Table 1 is a category of learning device validity.

Table 1. Categories of Validity of Learning Devices

\begin{tabular}{cc}
\hline Validity Criteria & Validity Level \\
\hline $85,01 \%-100,00 \%$ & Very Valid \\
$70,01 \%-85,00 \%$ & Valid \\
$50,01 \%-70,00 \%$ & Invalid \\
$01,00 \%-50,00 \%$ & Invalid \\
\hline
\end{tabular}

Response questionnaire analysis was obtained by determining the level of practicality, which is the score obtained divided by the highest score and multiplied by $100 \%$. Table 2 is a category of learning device validity. 
Table 2. Categories of Practicality of Learning Devices

\begin{tabular}{cc}
\hline Practicality Criteria & Practicality Level \\
\hline $81 \%-100 \%$ & Very practical \\
$61 \%-80 \%$ & Practical \\
$41 \%-60 \%$ & Practical enough \\
$21 \%-40 \%$ & Not Practical \\
$0 \%-20 \%$ & Not practical \\
\hline
\end{tabular}

Analysis of student KKM test results was done by t test using the SPSS 23 application, Paired-Sample t-Test. The hypothesis in the $t$ test is $\mathrm{H}_{0}=\mathrm{KKM}$ of students who use learning tools that are developed no better than KKM of students who use conventional learning, and $\mathrm{H}_{1}=\mathrm{KKM}$ of students who use learning tools that are developed better than KKM of students who use conventional learning. If $t$ arithmetic is greater than $t$ table $\left(t_{\text {count }}>t_{\text {table }}\right)$, then the null hypothesis is rejected. Before conducting the $\mathrm{t}$ test, normality test and homogeneity test were first performed. The normality test was carried out with the help of the SPSS 23 computer application Kolmogorov Smirnov Test with a significance level $\alpha=0.05$. The hypothesis of the normality test is $\mathrm{H}_{0}=$ data normally distributed, and $\mathrm{H}_{1}=$ data not normally distributed. $\mathrm{H}_{0}$ is accepted if the significance value> 0.05 . Homogeneity test was done using Levene test with the help of SPSS 23 application. The hypothesis of the homogeneity test is $\mathrm{H}_{0}=$ data has homogeneous data variance, and $\mathrm{H}_{1}=$ data has no homogeneous data variance. $\mathrm{H}_{0}$ is accepted if the significance value> 0.05 .

\section{Results and Discussion}

The product taht was produced from this research is a mathematics learning kit consisting of syllabus, lesson plans, and LKPD of Barisan and Series material. The development process begins with an analysis. Performance analysis found that teachers tend to use tools from MGMP, peers, and others. This is because the teacher has not been able to develop competency achievement indicators, set learning objectives at each meeting, and develop learning activities that make students active in learning.

The lesson plans and sequences used by teachers are combined into one for six meetings. The teacher arranges competency achievement indicators for several meetings and repeats the sentences in the basic competency. The formulation of learning objectives is combined into several meetings and does not yet contain the ABCD component. Learning activities are unclear and detailed so that when it was used by other teachers, questions will arise. Worksheets are also rarely used by teachers in the learning process. Teachers tend to use textbooks from school and worksheets provided by publishers.

Needs analysis found that most students do not have a good KKM based on KKM indicators. Student involvement in learning mathematics is still low. Learners only focus on learning only 15 minutes at the beginning of learning. When teachers ask questions, students tend to discuss with friends. This shows that students like to 
do a learning activity together. Therefore, learning can be done with a learning model that makes learning activities in groups. One learning model that can be used is the PBL model. PBL models provide problems at the beginning of learning that make students discuss to solve problems together.

The next product development is designing learning devices. Learning tools that are designed in accordance with BC related to ranks and series and apply PBL models, scientific approaches and contain KKM indicators. Figure 1 is an example of learning activities by applying the PBL model.

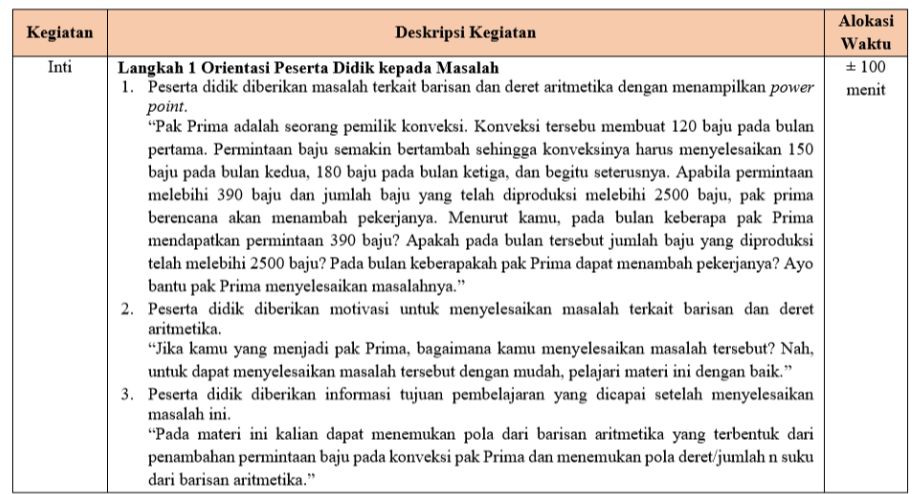

Figure 1. Problem Orientation Activities in RPP

\begin{tabular}{|c|c|c|}
\hline Kegiatan & Deskripsi Kegiatan & $\begin{array}{l}\text { Alokasi } \\
\text { Waktu }\end{array}$ \\
\hline Inti & $\begin{array}{l}\text { Langkah } 2 \text { Mengorganisasikan Peserta Didik untuk Belajar } \\
\text { 4. Peserta didik dibagi kedalam kelompok belajar dan diberikan LKPD-1 terkait barisan dan deret } \\
\text { aritmetika. } \\
\text { 5. Peserta didik mengamati dan mendiskusikan masalah } 1 \text { pada LKPD-1 yang telah ditampilkan } \\
\text { sebelumnya oleh guru menggunakan power point. (mengamati) } \\
\text { 6. Peserta didik diberikan kesempatan untuk bertanya hal-hal yang belum dipahami. (menanya) } \\
\text { 7. Peserta didik diberikan bantuan secara terbatas terkait kesulitan dalam memahami masalah. } \\
\text { Langkah } 3 \text { Membimbing Penyelidikan Kelompok } \\
\text { 8. Peserta didik mengidentifikasi masalah yang ada pada LKPD-1. (Menyatakan peristiwa sehari-hari } \\
\text { kedalam bahasa matematika) } \\
\text { 9. Peserta didik mengumpulkan informasi yang relevan dengan membaca buku matematika kelas XI } \\
\text { kurikulum } 2013 \text { edisi revisi } 2017 \text { penerbit Kemdikbud halaman } 191-196 \text { dan buku matematika } \\
\text { waib } 2 \mathrm{~B} \text { penerbit Erlanga halaman } 18 \text { - 40. (mengumpulkan informasi) } \\
\text { 10. Peserta didik menyelesaikan masalah berdasarkan informasi/data yang terkait dengan barisan dan } \\
\text { deret aritmetika. (menalar) (Menggunakan istilah/notasi/ rumus dan struktur untuk menyajikan } \\
\text { ide) } \\
\text { 11. Peserta didik dengan bimbingan guru menemukan pola barisan dan deret aritmetika dan } \\
\text { menemukan penyelesaian masalah. } \\
\text { 12. Peserta didik menyimpulkan hasil diskusi terhadap penyelesaian masalah. (Menarik kesimpulan } \\
\text { dari solusi yang diberikan) }\end{array}$ & $\begin{array}{l} \pm 100 \\
\text { menit }\end{array}$ \\
\hline
\end{tabular}

Figure 2. Activities Organizing Students and Guiding Group Investigations in RPP

Figure 2 shows the KKM indicators in learning activities found in the third step of the PBL model namely guiding group inquiry. Students are given guidance in stating daily events into the language of mathematics based on the problem given. The ability to use terms, notations or formulas and structures to present ideas is done by guiding students in solving problems based on information gathering. The third indicator of KKM is drawing conclusions from the solutions provided, the results of discussions that have been conducted in groups are then guided to make conclusions from the results of discussions that have been obtained. By guiding the students, KKM obiusly can be improved. 


\begin{tabular}{|c|l|c|}
\hline Kegiatan & \multicolumn{1}{|c|}{ Deskripsi Kegiatan } & $\begin{array}{c}\text { Alokasi } \\
\text { Waktu }\end{array}$ \\
\hline Inti & $\begin{array}{l}\text { Langkah 4 Mengembangkan dan Menyajikan Hasil Karya } \\
\text { 13. Peserta didik menyiapkan hasil diskusi kelompok secara rapi, rinci, dan sistematis. } \\
\text { 14. Peserta didik mempresentasikan hasil kerja kelompok di depan kelas. (mengkomunikasikan) } \\
\begin{array}{l}\text { Langkah 5 Menganalisis dan Mengevaluasi Proses Pemecahan Masalah } \\
\text { 15. Peserta didik mengevaluasi jawaban kelompok penyaji serta memberikan masukan kepada } \\
\text { kelompok penyaji difasilitasi oleh guru. }\end{array}\end{array}$ & $\begin{array}{l} \pm 100 \\
\text { menit }\end{array}$ \\
$\begin{array}{l}\text { 16. Peserta didik diberi kesempatan menyajikan hasil diskusi kelompok lain apabila terdapat jawaban } \\
\text { yang berbeda. Peserta didik diberikan penguatan untuk pemecahan masalah yang baik dari } \\
\text { masalah-1. }\end{array}$ & \\
\hline
\end{tabular}

Figure 3. Developing, Presenting, Analyzing and Evaluating Activities in the CSP

The fivth steps of the PBL model are explained in detail and systematically in the lesson plan so that they are easily understood and easily implemented in learning. Developing the KKM is also done by designing the LKPD by applying the PBL model and containing the KKM indicators. Figure 4 is an example of LKPD development that contains KKM indicators.

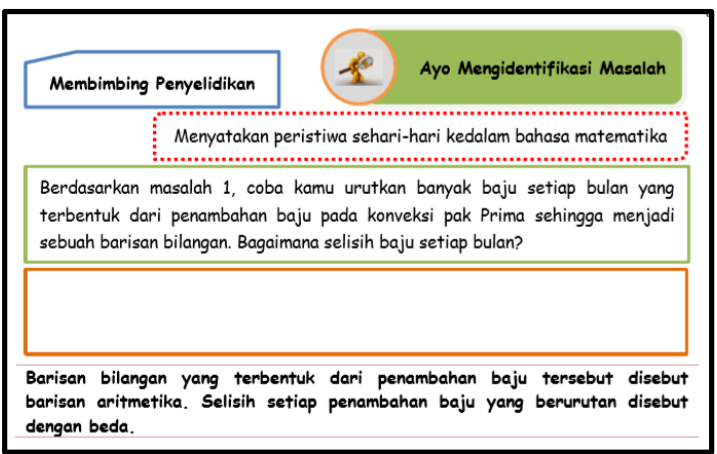

Figure 4. The First Indicator of KKM in LKPD

The KKM indicator contained in Figure 4 shows students are given guidance to develop the ability to express everyday events into the language of mathematics. Students are given questions and instructions that can make students state the problem given in the language of mathematics. KKM indicators use terms, notations or formulas and structures to present ideas can be seen in Figure 5.

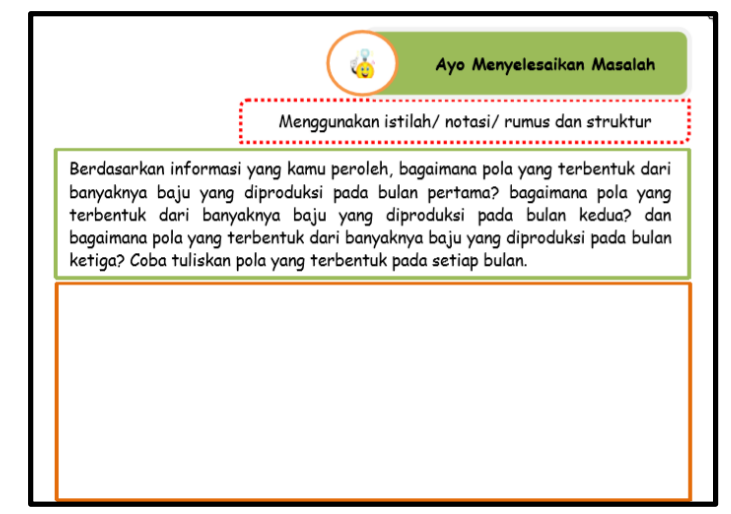

Figure 5. Second Indicator of KKM in LKPD

Figure 5 shows the ability to use terms, notations or formulas and structures to present ideas when solving problems. Students are given guidance in using notations and formulas and structures in steps to solve problems. The third 
indicator is drawing conclusions from the solutions provided. Indicators drawing conclusions from the solutions provided can be seen in Figure 6.

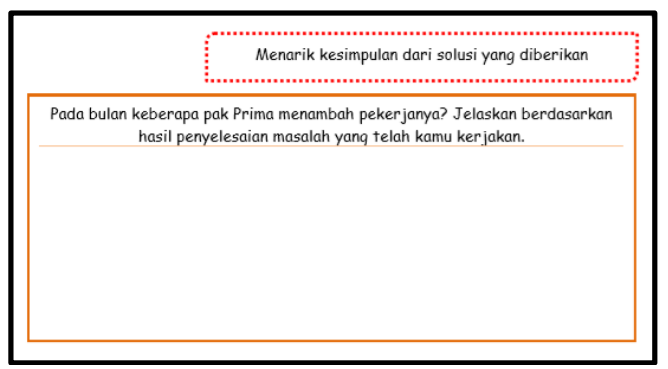

Figure 6. Third Indicator of KKM in LKPD

Figure 6 shows the ability to draw conclusions from the solutions given guided by directing students to the conclusions of the discussion results related to problem solving. Guidance is done by giving questions that can lead to conclusions from the solutions that have been obtained through activities in LKPD.

The results of the syllabus validity of the validator showed a value of $91.67 \%$ with very valid criteria, RPP showed a value of $91.30 \%$ with very valid criteria, and LKPD showed a value of $89.09 \%$ with very valid criteria, and an assessment of the KKM problem of $87.15 \%$ with very valid criteria. Learning devices that have met the valid requirements are then tested. A small group trial was conducted to see the readability of the LKPD that was developed. Students work to solve the problems that exist in LKPD with a small group of 4 people. The results of students' responses through the practicality questionnaire obtained a percentage of 96.13\% with very valid criteria. Most of the input and advice given from the small group regarding typos and the sentence sentences in the LKPD are still difficult to understand. These suggestions and input were revised before the large group trial.

Large group trials were conducted on students consisting of 35 people from the XI MIPA 6th grade. Group trials were conducted using learning tools in the form of lesson plans and work plans in the learning activities. The results of the responses of students from large groups through the questionnaire practicality showed a percentage value of $95.71 \%$ with very practical criteria. In addition, observations were made by teachers of the implementation of learning activities that have been previously designed. Observation of the implementation of learning activities observed by teachers in the field of mathematics through observation sheets. Based on observations made by the teacher, it was found that most of the activities contained in the lesson plan had been carried out in accordance with the design that had been made in the lesson plan. The teacher's response to the learning device is obtained through a teacher response questionnaire with a percentage of $96.00 \%$ with very practical criteria.

The next stage is the evaluation stage. The evaluation was carried out on the four previous stages by revising the learning tools and the effectiveness test was evaluated. The effectiveness test was conducted on the experimental class using the developed learning device, and the control class using the learning device of 
the subject teacher. After learning, the students are given a KKM test to see the difference in the student KKM after using the developed learning tool.

KKM test results of the experimental class and the control class were analyzed using the $t$ test. Before conducting the $t$ test, normality test and homogeneity test are first performed. The normality test is carried out by the Kolmogorov-Smirnov test using the SPSS 23 application. Table 3 is the normality test for the KKM test using the SPSS 23 application.

Table 3. Test Normality Test KKM Experiment and Control Class

\begin{tabular}{lccccc}
\hline \multicolumn{1}{c}{ Class } & N & Average & $\begin{array}{c}\text { Standard } \\
\text { Deviation }\end{array}$ & $\begin{array}{c}\text { Sig. } \\
\text { (2-tailed) }\end{array}$ & Information \\
\hline Experiment & 35 & 81,34 & 7,885 & 0,120 & Normal \\
Control & 35 & 68,29 & 7,683 & 0,070 & Normal \\
\hline
\end{tabular}

Table 3 shows the significance value of the experimental class and the control class greater than $\alpha=0.05$. Test the normality of the experimental class with sig $0.120>0.05$, which means that the value of the experimental class meets the normal criteria. Control class normality test with a sig value of $0.070>0.05$ is said to be normal. Both data from the experimental class and the control class meet the normality assumption. Then homogeneity test is done by using SPSS 23 application through Levene test. Table 4 is the result of homogeneity test of the experimental class and the control class using SPSS 23.

Table 4. Homogeneity test of Experiment Class and Control Class

\begin{tabular}{ccccc}
\hline Levene Statistics & df1 & df2 & Sig. & Information \\
\hline 0,174 & 1 & 78 & 0,678 & homogeneous \\
\hline
\end{tabular}

Table 4 shows that the significance value is $0.678>0.05$, so it can be concluded that the variance of the experimental class posttest group and the posttest control class is homogeneous. Then the difference test can be done by using Paired Sample t-Test to determine the difference between the experimental class KKM and the control class. Table 5 is the t-test results of the experimental class and the control class.

Table 5. The t test of Experiment Class and Control Class

\begin{tabular}{lcccccc}
\multicolumn{1}{c}{ Posttest } & N & Average & $\begin{array}{c}\text { Standard } \\
\text { Deviation }\end{array}$ & t & df & Sig. \\
\hline $\begin{array}{l}\text { Control Class - Experiment } \\
\text { Class }\end{array}$ & 35 & 13,057 & 6,426 & 12,021 & 34 & 0,000 \\
\hline
\end{tabular}

Table 5 shows the significant value of $0,000<\alpha=0.05$ which means that $\mathrm{H}_{-} 0$ is rejected or H_a is accepted. Therefore, it can be concluded that the KKM of students after using learning tools that are developed is better than students who do not use the learning tools that are developed. 


\section{Conclusion}

This development research produces learning tools by applying PBL models to improve the KKM of sequence and series material. Learning tools are said to be very valid, very practical, and effective after going through the validation process by qualified experts, and grade XI students to ensure practicality and effectiveness after going through the testing phase so that the KKM of students increases after using it.

\section{References}

Andri, S., Zulkarnain., \& Sehatta, S. (2019). Application of Cooperative Learning Models of Think Pair Share Type to Improve Students Mathematics Learning Outcomes. Journal of Educational Sciences, 3(2), 237-248.

Anik, Z. (2017). Pengembangan Perangkat Pembelajaran Kooperatif Tipe Stad dengan Metode Scramble pada Materi Sistem Koordinat. Jurnal Penelitian Pendidikan UNS, 24(2). Surabaya.

Daryanto., \& Aris, D. (2014). Pengembangan Perangkat Pembelajaran (Silabus, $R P P, P H B$, Bahan Ajar). Yogyakarta: Gava Media.

Dedeh, T. C., (2013). Peran Pembelajaran Berbasis Masalah untuk Meningkatkan Kemampuan Komunikasi dan Berpikir Kreatif serta Disposisi Matematika Siswa SMA. Infinity Journal, 2(2), 194-202.

Fatia, F. (2013). Kemampuan Komunikasi Matematis dalam Pembelajaran Statistika Elementer melalui Problem Based-Learning, Jurnal Cakrawala Pendidikan. 5(2), 267-277.

Guswinda., Putri, Y., \& Nahor, M. H. (2019). Improvement of Mathematical Problem Solving and Disposition Ability of MTs Students Through Strategies Think Talk Write in Cooperative Learning In Kuantan Singingi Regency. Journal of Educational Sciences, 3(3), 377-389.

Hanim, F., \& Erna, P. A. (2017). Efektivitas Lembar Kerja Siswa (LKS) Berbantuan Software Geogebra pada Materi Program Linear, Jurnal Pendidikan Matematika dan Matematika. 3(2), 103-110.

Jumanta, H. (2016). Metodologi Pengajaran. Jakarta: Bumi Aksara.

Miftahul, H., Kartini., \& Atma, M. (2019). Pengembangan Perangkat Pembelajaran Materi Segiempat dan Segitiga Kelas VII Melalui Model PBL. Jurnal Online Mahasiswa FKIP UR, 6(1), 1-15.

Nancy, A., \& Mustaji. (2013). Pengembangan Bahan Ajar dengan Model ADDIE untuk Mata Pelajaran Matematika Kelas 5 SDS Mawar Sharon Surabaya. Jurnal Kwangsan, 1(1), 1-15.

Puji, K., Maimunah., \& Atma, M. (2019). Development of ICT-Based Mathematical Media on Linear Program Materials to Improve Motivation Learning Students. Journal of Educational Sciences, 3(2), 19-204.

Sumarno,. \& Dhoriva, U. W. (2014). Pengembangan Perangkat Pembelajaran pada Materi Pokok Kalkulus SMA Kelas XI Semester 2. Jurnal Riset Pendidikan Matematika, 1(2), 257-267.

Titi, S., Syarifah, N. S., \& Yenita, R. (2017). Pengembangan Perangkat Pembelajaran Matematika Berbasis Kurikulum 2013 pada Materi Bangun 
Ruang Sisi Data dan Lingkaran untuk Siswa Kelas VII Tingkat SMP/MTS. Edumath, 4(1), 59-66.

Wahid, U., (2012). Membangun Kemampuan Komunikasi Matematis dalam Pembelajaran Matematika, Infinity Journal, 1(1).

Yenita, R., Putri, Y., Sehatta, S., Hadiyanta, A., \& Andespa, S. (2017). ComputerBased Media for Learning Geometry at Mathematics Class of Secondary Schools. Journal of Educational Science, 1(1), 79-91.

How to cite this article:

Atika, N., Roza, Y. \& Murni, A. (2020). Development of Learning Tools by Application of Problem Based Learning Models to Improve Mathematical Communication Capabilities of Sequence and Series Materials. Journal of Educational Sciences, 4(1), 62-72. 